\title{
Choosing Open Innovation Intermediaries through their web-based platforms
}

Barbara Aquilani. University of Tuscia, Viterbo. Italy. b.aquilani@unitus.it

Tindara Abbate. University of Messina. Italy. abbatet@unime.it

Gandolfo Dominici. University of Palermo and Business Systems Laboratory. Italy. gandolfo.dominici@libero.it

\begin{abstract}
This paper examines the services provided by Open Innovation Intermediaries (OIIs) through their web-based platforms, in order to understand how OIIs can effectively support innovation seekers in their innovation processes. Relying on the existing literature exploring the roles and functions of web-based OII platforms, we carried out an exploratory and comparative qualitative study to identify the services available, to classify them by the various phases of the innovation processes in which they can be beneficial, and to link them to general roles and functions. Our analysis of the services provided by OII platforms sheds light on the dynamics of innovation seekers' choices, and gives meaningful insights that can help improve this information and these services, so that OIIs can improve their offer in terms of complementary resources and knowledge for the innovation processes.
\end{abstract}

Keywords: Open Innovation Intermediaries; Web-based platforms; Intermediaries' services, Seekers in Open Innovation contexts.

\section{INTRODUCTION}

Open Innovation Intermediaries aim to make it easier to adopt the so-called Open Innovation paradigm. Open Innovation Intermediaries' web-based platforms support innovation seekers looking for external ideas, knowledge, and innovations in choosing the most appropriate Intermediary. 
The Open Innovation (OI) approach is primarily focused on opening up firms' innovation processes to external actors (Chesbrough, 2003; Christensen et al., 2005; Gann, 2005; Helfat, 2006; Enkel et al., 2009; Dahlander and Gann, 2010; Harison and Koski, 2010; Herzog and Leker, 2010; Huizing, 2010; Manzini et al., 2012; Chesbrough and Bogers, 2014; West and Bogers, 2014). Following this paradigm, firms should involve external actors-that is, solvers such as universities, research centres, professionals, other firms, communities, and individuals - to acquire new ideas and resources, to intensify and accelerate their internal innovation processes, and to expand markets using their innovative outcomes (Chesbrough et al., 2006).

Access to external knowledge sources, as well as the search for solvers, can be facilitated by Open Innovation Intermediaries (OIIs), which are defined as organizations that stimulate, operate, and support any aspect of innovation processes (Howells, 2006; Stewart and Hyysalo, 2008; Sieg et al., 2010; Hakanson et al., 2011; Ollila and Elmquist, 2011; Tran et al., 2011; Katzy et al., 2013; Ye and Kankahalli, 2013).

Academic contributions on OIIs have mainly focused on their critical roles in innovation processes (Gassmann et al., 2011; Agogue et al., 2013; Mirkovski et $a l ., 2015$ ), their wide range of functions and activities (Howells, 2006; Daziel, 2010), their modes of interaction connecting innovation players and their related successes (Lakhani, 2008), their unique abilities, competences and capabilities to effectively activate and manage knowledge combination and recombination processes (Verona et al., 2005) (including in new product development processes) (Colombo et al., 2014), the value that seekers can derive from interacting with them (Roijakkers et al., 2014), their life cycle (Hallerstede, 2013) and recently also on trying to build theories and models for their market (Hossain, 2012). In addition, contributions concerned with OIIs consider their advanced web-based platforms as the virtual locus in which OIIs effectively stimulate, link, coordinate, and sustain interactions and exchanges of ideas and knowledge between 'innovation seekers' and 'innovation solvers', and find appropriate partners worldwide (Howells, 2006; Gassmann et al., 2011), highlighting the IT role also following a Service-Dominant Logic perspective (Lusch and Nambisan, 2015). 
Nonetheless, very little evidence exists of the services delivered by OII through their advanced web-based platforms. Services represent the practical way in which OIIs operate and support seekers; it is therefore clear that their differences in terms of services have to be considered by seekers as a criterion for choose the best suited to each moment of the innovation process. In fact, the complementary resources, knowledge, and solutions, needed by the seeker, can emerge both at the starting point and at each phase of the innovation process in different ways. In consequence, seekers have to select the right OII, taking into account the real problem to be solved; looking at roles, functions, and the OII's stated mission does not tell the seeker exactly how the OII can really help at a given time or with a specific issue. Moreover, each seeker firm and each OII's peculiarities need to be harmonized to lead to a successful innovation process; services represent the way in which these actors can interact in practice; they have to be profoundly known before the right OII can be selected.

To address this gap in the literature and to give some practical insights to seekers interested in approaching Open Innovation through OIIs, two main research questions arise:

1) Which are the services that innovation seekers can obtain through web-based OII platforms?

2) Which are the differences in the ways OIIs fulfil their roles and functions through the web-based services they provide?

To answer to these research questions, following a brief review of earlier studies on the roles and functions of OIIs, we carry out an explorative and comparative qualitative analysis considering eight different web-based OII platforms to make clear the differences in terms of services provided by these Intermediaries. In doing so, we also distinguish services by considering the various phases in which an innovation process develops, with the aim of clarifying which services can be benefited at each stage of the innovation process by choosing different OIIs. Moreover, we link the services found on web-based OII platforms to the roles and functions already identified in the literature to show how these can be differently interpreted by each individual OII, making it clear that even if these can be shared amongst OIIs, then the activities carried out can 
vary significantly, calling for a careful selection of intermediaries. The paper ends with a discussion of the results and with a conclusion, which also contains theoretical and managerial implications, further research steps, and the limitations of the study.

\section{ROLES OF OPEN INNOVATION INTERMEDIARIES}

A wide range of terms is used in different research fields to define OII (Mantel and Rosegger, 1987; Bessant and Rush, 1995; Hargadon and Sutton, 1997; Winch and Courtney, 2007): knowledge intermediaries, superstructure organizations (Lynn et al., 1996), technology brokers (Provan and Human, 1999), infomediaries (Hagel and Rayport, 1997), innomediaries (Sawhney et al., 2005; Roijakkers et al., 2014), and cross-sourcing initiatives (Sieg et al., 2010).

The common denominator of these definitions is that the intermediaries are always oriented to bridge the gaps between resources and knowledge by introducing, connecting, and facilitating interactions and relationships among diverse external parties that would otherwise be disconnected (Hargadon, 1998; Hargadon and Sutton, 2000) and would difficultly communicate (Flensburg, 2009). They can therefore contribute to decreasing innovation costs and time related to the development of new products and technologies, rapidly involving complementary capabilities in knowledge generation and acquisition processes, and increase the opportunity of finding the appropriate paths for bringing technologies to the market (Diener and Piller, 2010).

According to Howells (2006), innovation intermediaries - considered generally as independent third parties - can be defined as agents or brokers "helping to provide information about potential collaborators; brokering a transaction between two or more parties; acting as a mediator, or go-between, bodies or organizations that are already collaborating; and helping find advice, funding and support for the innovation outcomes of such collaborations". The crucial role of these intermediaries during complex innovation processes has been examined from different perspectives: (a) scanning information and identifying needs (Diener and Piller, 2010; Gassmann et al., 2011); (b) knowledge transfer, experience sharing, and diffusion (Diener and Piller, 2010; Gassmann et al., 2011); (c) brokering for problem solving (Agogue et al., 2013); (d) intermediation 
for technology transfer (Lichtenthaler and Ernst, 2008; Agogue et al., 2013); and (e) systems and networking (Gassmann et al., 2011; Agogue et al., 2013).

Several studies have explored the main functions from the fundamental role of the middleman who operates on behalf of his client when dealing with diverse clients (Howells, 2006). More specifically, OIIs perform a wide range of core functions, linked appropriately with the above mentioned roles, which are the following: a) connecting, involving, and mobilizing different actors in innovation processes (Hakanson et al., 2011; Agogue et al., 2013); b) facilitating the identification of suitable technology commercialization opportunities (Lichtenthaler and Ernst, 2008), diffusing technology transfer (Diener and Piller, 2010) and supporting "accreditation, validation and regulation, protection of the results" (Howells, 2006, p. 721); c) processing knowledge by connecting companies with problems to solvers from different domains and industries (Howells, 2006; Stewart and Hyysalo, 2008; Lopez and Vanhaverbeke, 2009; Hakanson et al., 2011; Ye and Kankanhalli, 2013); d) solving (or mitigating) conflicts between stakeholders (Agogue et al., 2013); e) foresight, diagnostic, and information processing (Howells, 2006), working closely with clients to define problems and find solutions (Ye and Kankanhalli, 2013), as well as brokering information flows (Diener and Piller, 2010).

To perform these heterogeneous functions, OIIs can use web-based platforms that facilitate interactions and more easily build networks among different entities worldwide, transforming this traditional one-way communication form into a persistent global dialogue (Sawhney et al., 2005).

As a relatively new phenomenon, OII services still need further research to investigate some of their peculiar aspects. Although a number of academic contributions have focused on their roles, functions (Howells, 2006; Lopez and Vanhaverbeke, 2009), activities (Bakici et al., 2012; Colombo et al., 2014), and mechanisms (Gassmann et al., 2011) to foster open innovation processes, there is still a lack of research on the services provided by OIIs and how they foster innovation processes through the integration of internal and external knowledge sources. Moreover, OIIs can use their web-based platforms in different ways: some of them function as a form of first contact, with services mostly provided offline; some are the real locus of all their intermediation activities; and others 
work either way, depending on the seeker's preference (Roijakkers et al., 2014). We therefore begin filling this gap in the literature by focusing our study on OII services provided directly online, as this better suits the methodology used (for example, we didn't carry out in-depth interviews with OIIs that provide their services offline); it also makes the real support OIIs provide through their webbased platforms clearer, and helps to suggest to seekers that they look at the services provided when choosing the most suitable OII at each given time, rather than examining general roles, functions and stated mission.

\section{RESEARCH METHODOLOGY}

To pursue our research objectives and to answer our research questions, we used an explorative and comparative analysis with the multiple case-study methodology (Yin, 2003). We adopted this methodology, because it allows the exploration of the phenomenon of interest - that is, of the services provided by innovation intermediaries through their web-based platforms, in order to facilitate and support seekers and solvers in the challenging innovation context.

We examined eight web-based OII platforms for how they provide a wide range of services oriented at sustaining innovation processes. To choose our sample, we considered that the birth and development of OIIs can be divided into two distinct periods: the first runs from 1999 to 2002; the latter concerns the years between 2009 and 2010 (Bakici et al., 2012). Following this evolutionary trend, we created two distinct subsamples of intermediaries and examined four platforms from the first period and the same number from the second period. Reference was made to Bakici et al. (2012), who fundamentally examined five of the selection of subsamples of the more recent operators (2010-2012). From this group, it was necessary to exclude challenge.gov, as it is a US General Services Administration property (Bakici et al., 2012) and not directly comparable under various profiles with other spontaneously developed private innovation intermediaries. Also, the Presance intermediary was excluded, as it is no longer accessible. In order to consider recent trends in Europe that are not yet available in the literature, we added an Italian Open Innovation Intermediaries founded in this same period. The first subsample contains Big Idea Group, Openideo, Inpama, and mercatodellinnovazione.it. 
The OIIs chosen have been frequently studied and cited in the literature; these are NineSigma (Chesbrough, 2006; Bakici et al., 2012; Hossain, 2012), Innocentive (Huston and Sakkab, 2006; Lakani et al., 2007; Sieg et al., 2010; Hossain, 2012), yet2.com (Lichtenthaler, 2008; Abbate and Coppolino, 2011; Hossain, 2012) and Big Idea Group (Lopez and Vanhaverbeke, 2009).

Once we selected the innovation intermediaries, we designed our research analysis in two main steps. First of all, we examined contributions to the academic literature, official reports, dossiers, and documents in order to obtain useful data and information on these OIIs, especially on their roles and functions.

We then made several rounds of desk analysis directly on each of these webbased OII platforms, in order to compare their available and usable services. In doing so, we classified the services, focusing on the different innovation phases normally followed in an Open Innovation context when an Intermediary intervenes, derived from the literature on the roles and functions of OIIs. To track each research activity, we developed ad hoc spreadsheets using the Excel program. This survey was carried out between the 2nd and 13th of February 2015, ensuring that the material from literature was up to date.

It should be noted here that it is not possible to statistically generalize results from an exploratory multiple case study analysis (Yin, 1984). However, our findings can nonetheless inform future theoretical and empirical studies regarding OIIs and their services to facilitate the adoption of OI in the context of different activities.

\section{RESULTS}

\subsection{Services provided by OIIs: a comparison}

The range of services provided by OIIs is wide and, as highlighted by Howells (2006), shows interesting elements of selection for seekers, as shown in Annex 1.

As far as "connection mode" is concerned, all OIIs allow the contact between seekers and solvers mediated by their own platform, being the main aim of OII creation, while only five of the sample web-based platforms support direct contact between seekers and solvers (NineSigma, Big Idea Group and Big Idea Groups the Nokia owned platform- are the exceptions). The only marketplaces used for 
the exchange of complete technologies or patents are yet2.com, Inpama, and mercatodellinnovazione.it.

The "Communication services" are, in most cases, enabled by the OII platforms and the e-mail, even if some OIIs allow some personal communications as NineSigma, Innocentive for the Grand Challenges and by telephone for the Premium Challenges, yet2.com, Big Idea Group, Big Idea Groups and mercatodell'innovazione.it.

Under the heading "Services providing support for contact and initiation of innovation process", or what can be understood as the process "from innovative idea to product", it is possible to clearly identify some generic services that are common to many web-based OII platforms (such as "Acceptance services, text preparation, and revision of post", "Preventive analysis ideas/demand/problem", "Information guide/support to a shared innovation process", "communication and distribution to community members or specific partners", "Support services by experts on request/project", etc.), while other, more specialized, services characterize only some web-based platforms; this is an interesting factor of differentiation. For example, mercatodellinnovazione.it, NineSigma and yet2.com offer the possibility of evaluating "existing and emerging technology to guide firms in innovation choices", while other intermediaries, such as NineSigma, Innocentive (only for Premium Challenges and Grand Challenges), yet2.com and Inpama, offer "services seeking specialized partners to comply with the prerequisites dictated by the firm" and as well as Big Idea Group and mercatodell'innovazione.it foster and sustain the "creation of ad hoc groups for the resolution of problems". Four of the OII web-based platforms we analyzed offer services deemed to the "definition and evaluation of the solutions found" (Innocentive -only for Premium Challenges and Grand Challenges-, yet2.com, Big Idea Group and Openideo). Only Innocentive provides "services defining the price range" of innovation exchanged, probably due to its mission as a marketplace for innovations.

The more widespread services are the "technical-technological services to support innovation" and "support for the launch of innovation and 'licence-out' services", while "product design support through prototype" services are only 
provided by NineSigma, Innocentive - Premium Challenges-, Big Idea Group and Openideo.

"Technical-technological consultancy services to the firm" are found in the case of NineSigma, while mercatodellinnovazione.it offers "support identifying aspects and/or projects for further investment by the firm". Besides these, yet2.com offers "services to improve existing and/or integrable technology in the firm".

Big Idea Group and Inpama stand out with their "consultancy services" for financial and marketing questions, while yet2.com offers services focused specifically on "seeking partners for venture capital operations", and mercatodellinnovazione.it concentrates its consultancy service on firm internationalization processes and activities.

NineSigma, Innocentive, and Openideo offer the interesting possibility of participating in "big innovation projects" concerning relevant subjects such as environment, security, nutrition and so on, while only NineSigma provides "training and coaching" services and the opportunity of carrying out sophisticated services, such as "psychometric tests on team leaders and project managers".

Summarizing, looking to services provided it is clear that the four more recently created OII platforms are more specialized than the older ones. Big Idea Groups is a firm owned platform to implement OI thanks to the experts and the community insights; Openideo is really focused on the idea and the design, but not on following all the innovation process thus avoiding redundant services; Inpama and Innocentive are marketplaces with the former more focused on competition, a smaller number of services provided; also mercatodell'innovazione.it is a marketplace, which has recently divided the platform provided services activity from its offline consultancy services through Innovuum, a new purposely created firm.

\subsection{Linking services provided to OII roles and functions}

Relying on the information retrieved from the existing literature on the roles and functions of OIIs, and on the data already collected in our study, we build a table linking the roles, functions, and services provided in general and for each of the investigated OIIs (see Annex 2). 
It is evident from Annex 2 that several services provided by OIIs through their web-based platforms not only differ from each other (for example, in, "definition and evaluation of solutions found"), but also that some OIIs do not play certain roles or enact some intermediary functions, such as IdeasProject and Inpama in our sample.

As stated on its web-based platform, IdeasProject "is an online community for everybody from all around the world to brainstorm. It enables the two-way exchange of ideas between users and developers around innovation powered by Nokia" (www.nokia-ideasproject.com).

This explains why the services provided by this platform specifically support Nokia's innovation projects and, as a consequence, the only roles fulfilled are "networking" and "intermediation for technology transfer", while the functions are carried out only on behalf of Nokia's innovation activities.

Inpama is a useful "marketplace to sell inventions and patents" that is available for free to inventors, patent owners, "creative people", and entrepreneurs (http://www.Inpama.com). For this reason, it is not interested in "scanning information and articulating needs" since it supports solvers in their search for innovation seekers and helps them with a guide and some specific tools and materials that let them commercialize their invention or idea on their own.

From Annex 2 it is also clear that roles and functions, do not correspond to the same services made available for seekers and solvers. This, indeed, depicts a more heterogeneous panorama than the one that so far can be found in the literature based on OIIs roles and functions. Looking at the "networking" role and considering the OIIs services, it becomes clear that the network is built linking different partners and needs to follow the main goal of the specific OII. NineSigma, the most important OII at global level seems to be not interested in patents, unlike yet2.com that focuses its activity on patents. The second OII role we considered is the intermediation for technology transfer. Intermediation for technology transfer is not the basis for services provided by NineSigma or Innocentive which focus on ideas and knowledge in whichever form (see the "Knowledge transfer/experience sharing" role in Annex 2), not necessary linked to the technology field. This is because these OIIs allow the contact with the 
community (directly for Innocentive, only through the platform for NineSigma) which is normally created by customers and not only by experts. Therefore they can only provide new knowledge, ideas and insights.

The "problem solving" role make clear (see Annex 2) that there are great differences among OIIs, In fact, only few OIIs are able to provide services deemed to help seekers and solvers to unravel all the problems arising during the full development of the innovation process. These differences are determined by both the main goal of the OII and the different expertise they want to provide. This information is of real value for the choice of the right OII. Indeed, if the seeker is not fully aware of all the possible risks and problems which may arise during the innovation journey, he would better consider an OII that is able to provide the complementary expertise. "Scanning information and articulating needs" role is another service that not all OII provide.

We found a gap in the existing literature on OII that is it lacks to highlight the OII original role in enhancing new and widespread research projects starting from an original idea/suggestion. In the sample we analyzed we found that NineSigma, Innocentive and Openideo provide the opportunity to participate to meaningful challenges for the main world social challenges. Considering that this activity is not carried out on behalf some identified seekers, but independently created by the OII, it would be worth to consider the OII role in enhancing the innovation activity of all interested parties aiming to foster social well-being.

\section{DISCUSSION AND CONCLUSION}

\subsection{Discussion}

In answer to our first research question on how service-seekers can gain benefit through the services provided by web-based OII platforms, our results show significant difference between intermediaries. Some OIIs offer a wide range of services, sometimes unexpected (such as training and coaching for NineSigma), and are able to fully follow the seekers' innovation processes, providing all the needed complementary resources and knowledge - even if solvers can only be contacted through their intermediation, and not through the web-based platform (e.g., Nine-Sigma). Other OI intermediaries are more focused on purposely created services based on their more specific goals; they therefore have a different 
attitude towards the exchange of ideas, innovations, and sometimes patents. These OIIs are not interested in providing the "full" support available from other OII platforms, but they do allow direct contact with the solver (e.g., yet2.com). Moreover, the services provided by the OIIs in our sample are targeted at particular OII knowledge, resources, and goals; they are consequently more suited to requirements for specific resources and knowledge at specific stages of the seeker innovation process. We can thus assert that examining the services provided may be a better criterion than considering the OII's stated mission, general roles, and functions. Moreover, we found that only few OIIs could provide new opportunities to innovate for firms through their "Grand Challenges" projects which could open new scenarios for those firms and a first approach to OI.

Answering our second research question on the ways in which OIIs fulfil their roles and functions through web-based services, our results contradict some of the literature on the topic, which asserts that each OII fulfils all roles and functions (Howells, 2006; Bakici et al., 2012; Colombo et al., 2014). In our sample, we found that it is not true that each OII fulfils all roles and functions. General roles and functions have their value, but are not able to support seekers in their choice between intermediaries; services can help indicate the real added value provided by each OII for the seeker's needs at each phase of the innovation process, being aware of the seekers' proper knowledge, resources and capabilities to foster the innovation process. An entrepreneur who has developed an idea and would like to sell it is unlikely to pay for the use of NineSigma's services, instead of using Inpama, a free OII targeted to inventors' needs. Then again, for a patent, the bestsuited OII would likely be yet2.com, and so on.

\subsection{Theoretical implications}

From a theoretical point of view, our study moves a step forward towards a better understanding of OII services' roles and functions. Our study sheds the light on the more specialized and recent services provided by OIIs platforms. In particular we analyzed their clear intent, mission and different expertise in carrying out their activities and give shape to the services provided to seekers and solvers. These insights still deserve more attention with the aim of understand the OII practical role in supporting firms willing to implement OI. The study highlights that OIIs 
can no longer be considered as mere "mediators", "brokers", "third parties", etc. between seekers and solvers, but deserve a new consideration in the innovation scenario. OIIs activities, indeed, go often far beyond their primary aim, supporting seekers and solvers as full range consultants, providing advices and all complementary resources which are necessary to successfully carry out the firms' innovation processes. Moreover, if fulfilled to enhance the social well-being, some OIIs are able to create their own new innovation opportunities linked to widespread innovation projects able to become active and supporting part of the innovation scenario. This aspects deserve a more in-depth study.

\subsection{Practical implications}

From a practical point of view, the paper clarifies that the OII selection to implement an OI process should be based on the services offered, instead of on general roles and functions which are not really always fulfilled. Indeed, services are the practical interaction mode that seekers and OIIs have to turn open innovation processes into successes. In this context, the "map" of services provided in this paper, witnesses the differences among the service offered the OIIs we analyzed. Morevoer our analysis offers a framework to help firms to find which are the services available from each OII web-based platform. Being aware of the services available on OII platforms may help firms to identify which of them can be available at each stage of the OI process. Bearing in mind which knowledge, resources, capabilities are necessary complete their own OI, is pivotal for firms to evaluate the relevance of the features provided by the different OIIs. In doing so, innovation seekers could identify the OII that better fit to each step of their innovation process basing their choices on services that match with their own innovation requirements, in terms of internal resources and capabilities.

This approach to OII is of major value to exploit the full potential of services available on the market. Moreover, firms should be aware and consider the innovation opportunities autonomously offered by some OII through the Grand Challenges tool, trying to widen their innovation network and acquiring new knowledge and resources participating to these widespread projects. 


\subsection{Limitations and future research}

We are aware that the main limitations of this paper are associated with both the explorative nature of the empirical research and the small number of cases investigated here. The topic still needs further research, including, for instance, an extensive empirical analysis of all OIIs, considering also the services they provide offline (as for instance those recently implemented by mercatodell'innovazione.it through Innovuum). Further research could also be conducted on several ways, as for instance: using interviews to better study how seekers select OIIs; using a longitudinal analysis to evaluate the change in OIIs over time and the rationale for such change; carrying out an analysis of the weights assigned by seekers to specific categories or individual services; or studying how seekers suggest evaluating OII efficacy and success (e.g., new products, new patents).

\section{REFERENCES}

ABBATE, T.; COPPOLINO, R. (2011): "Knowledge sharing and innovation: the contribution of innovation intermediaries", In De Marco M. (eds.), Information Systems: Crossroads for Organization, Management, Accounting and Engineering, Springer-Verlag, Berlin Heidelberg.

AGOGUE, M.; BERTHET, E.; FREDBERG, T.; LE MASSON, P.; SEGRESTIN B., STOETZEL, M., WIENER, M.; YSTRÖM (2013): “A Contingency Approach to Open Innovation Intermediaries: The Management Principles of the "Intermediary of the Unknown"", Paper presents at the 13 Conference of European Academy of Management (EURAM), "Democratizing Management", Instanbul/TR, 26-29 June.

BAKICI, T.; ALMIRALL, E.; WAREHAM J. (2012): 'The Underlying Mechanism of Online Open Innovation Intermediaries', Retrieved from http://ssrn.com/abstract=2141908

BESSANT, J.; RUSH, H. (1995): "Building Bridges for Innovation: The Role of Consultants in Technology Transfer", Research Policy, vol. 24, n. 1: 97-114. http://dx.doi.org/10.1016/0048-7333(93)00751-E 
CHESBROUGH H.W. (2003): "Open innovation the new imperative for creating and profiting from technology”, Boston, MA: Harvard Business School Press.

CHESBROUGH, H.W. (2006): "Open business models: how to thrive in the new innovation landscape”, Cambridge, MA: Harvard Business School Publishing.

CHESBROUGH, H.W.; VANHAVERBEKE, W.; WEST, J. (2006): "Open innovation: A research agenda", In Chesbrough, H. W. Vanhaverbeke W. and West J. (eds.) Open Innovation: Researching a new paradigm (pp. 285-307), Oxford: Oxford University Press.

CHESBROUGH H.; BOGERS M. (2014): "Explicating Open Innovation. Clarifying an emerging paradigm for understanding innovation", In Chesbrough H., Vanhaverbeke W. and West J. (eds.), New frontiers in Open Innovation (pp. 328), Oxford (UK): Oxford University Press. http://dx.doi.org/10.1093/acprof:o so/9780199682461.001.0001

CHRISTENSEN, J.F.; OLESEN, M.H.; KJAER, J.S. (2005): 'The industrial dynamics of open-innovation - Evidence from the transformation of consumer electronics', Research Policy, vol. 34: 1533-1549. http://dx.doi.org/10.1016/j.re spol.2005.07.002

COLOMBO G.; DELL'ERA C.; FRATTINI F. (2014): 'Exploring the contribution of innovation intermediaries to the new product development (NPD) process: a typology and an empirical study', $R \& D$ Management, vol. 45 , n. 2:1 26-146.

DAHLANDER, L.; GANN, D.M. (2010): 'How open is innovation?', Research Policy, vol. 39: 699-709. http://dx.doi.org/10.1016/j.respol.2010.01.013

DAZIEL M. (2010): 'Why do innovation intermediaries exist?', Summer Conference 2010 "Opening Up Innovation: Strategy, Organization and Technology”, Londra. http://bit.ly/1TuYjZq

DIENER K.; PILLER F. (2010): "The market for open innovation: An executive report structuring the market for support and consultancies for open innovation”, [n.p.], RWTH AACHEN UNIVERSITY-TIM Group. http://bit.ly/1QpKtTU 
ENKEL, E.; GASSMANN, O.; CHESBORGH, C. (2009): 'Open R\&D and open innovation: Exploring the phenomenon', $R \& D$ Management, vol. 39, n. 4: 311316. http://dx.doi.org/10.1111/j.1467-9310.2009.00570.x

FLENSBURG, P. (2009), 'An enhanced communication model', The International Journal of Digital Accounting Research, vol. 9: 31-43. http://dx.doi.org/10.4192/1577-8517-v9_2

GANN, D.M. (2005): 'Book review: Open innovation: The new imperative for creating and profiting from technology', Research Policy, vol. 34: 122-123. http://dx.doi.org/10.1016/j.respol.2004.10.001

GASSMANN, O.; DAIBER, M.; ENKEL, E. (2011): 'The role of intermediaries in cross-industry innovation processes', $R \& D$ Management, vol. 41, n. 5: 457469. http://dx.doi.org/10.1111/j.1467-9310.2011.00651.x

HAGEL J.; RAYPORT J.F. (1997): 'The new infomediaries', The McKinsey Quarterly, vol. 4: 54-70.

HAKANSON, L.; CAESSENS P.; MACAULAY S. (2011): 'InnovationXchange: a case study in innovation intermediation', Innovation: Management, Policy \& Practice, vol. 13: 261-274. http://dx.doi.org/10.5172/impp.2011.13.2.261

HALLERSTEDE, S.H. (2013): Managing the Lifecycle of Open Innovation Platforms. Heidelberg: Springer. http://dx.doi.org/10.1007/978-3-658-02508-3

HARGADON, A.B. (1998): 'Firms as knowledge brokers: lessons in pursuing continuous innovation', California Management Review, vol. 40, n. 3: 209-227. http://dx.doi.org/10.2307/41165951

HARGADON A.; SUTTON R. (1997): 'Technology brokering and innovation in product development firm', Administrative Science Quartely, vol. 42, n. 4: 716749. http://dx.doi.org/10.2307/2393655

HARGADON A.; SUTTON R. (2000): "Building an innovation factory", Harvard Business Review, vol. 78, n. 3: 157-166.

HARISON, E.; KOSKI, H. (2010): 'Applying open innovation in business strategies. Evidence from Finnish software firms', Research Policy, vol. 39: 351359. http://dx.doi.org/10.1016/j.respol.2010.01.008 
HELFAT, C.E.C. (2006): 'Book review of open innovation: The new imperative for creating and profiting from technology', Academy of Management Perspective, vol. 20, n. 2: 1-86. http://dx.doi.org/10.5465/AMP.2006.20591014

HERZOG, P.; LEKER, J. (2010): 'Open and closed innovation: Different innovation cultures for different strategies', International Journal of Technology Management, vol. 52, n. 3: 322-343. http://dx.doi.org/10.1504/IJTM.2010.035979 HOSSAIN, M. (2012): "Performance and Potential of Open Innovation Intermediaries", Procedia - Social and Behavioral Sciences, vol 58: 754-764. doi:10.1016/j.sbspro.2012.09.1053 http://dx.doi.org/10.1016/j.sbspro.2012.09 .1053

HOWELLS, J. (2006): 'Intermediation and the role of intermediaries in innovation', Research Policy, vol. 35, n. 7: 715-728. http://dx.doi.org/10.1016/j.re spol.2006.03.005

HUIZING, E.K.R.E. (2010): “Open innovation: State of the art and future perspectives", Technovation, vol. 31, n. 1, pp. 2-9. http://dx.doi.org/10.1016/j.tec hnovation.2010.10.002

HUSTON, L.; SAKKAB, N., (2006) 'Connect and develop inside Procter and Gamble new model for innovation', Harvard Business Review, vol. 84, n. 3: 5866.

KATZY, B.; TURGUT, E.; HOLZMANN, T.; SAILER, K. (2013): 'Innovation intermediaries: a process view on open innovation coordination', Technology Analysis \& Strategic Management, vol. 25, n. 3: 295-309. http://dx.doi.org/10.108 0/09537325.2013.764982

LAKHANI, K.R. (2008) Innocentive.com, Harvard Business School Case, 608170, June.

LAKANI, K.R.; JEPPESEN, L.B.; LOHSE, P.A.; PANETTA, J.A. (2007): 'The value of openness in scientific problem solving', Harvard Business School Working Paper 07-050.

LICHTENTHALER, U. (2008): 'Open innovation in practice: an analysis of strategic approaches to technology transaction', I.E.E.E. Transaction on Engineering Management, vol. 55: 148-157. http://dx.doi.org/10.1109/TEM.2007.912932 
LICHTENTHALER, U.; ERNST, H. (2008): 'Innovation intermediaries: why internet marketplaces for technology have not yet met the expectations', Creativity and Innovation Management, vol. 17, n. 1: 14-25. http://dx.doi.org/10.1111/j.1467-8691.2007.00461.x

LOPEZ, H.; VANHAVERBEKE, W. (2009): "How innovation intermediaries are shaping the technology market? An analysis of their business model". Retrieved from: http://mpra.ub.uni-muenchen.de/20458/

LUSCH R.F.; NAMBISAN S. (2015): 'Service innovation: a Service-Dominant Logic perspective', MIS Quarterly, vol. 39, n. 1: 155-175.

LYNN G.S.; MORONE J. G.; PAULSEN A.S. (1996) 'Marketing and discontinuous innovation: the probe and learn process', California Management Review, vol. 38, n. 3: 8-37. http://dx.doi.org/10.2307/41165841

MANTEL, S. J.; ROSEGGER, G. (1987): "The role of third-parties in the diffusion of innovations: a survey", In Rothwell, R. and Bessant, J. (eds.), Innovation: Adaptation and Growth, Amsterdam: Elsevier. 123-134.

MANZINI R.; LAZZAROTTI, V.; PELLEGRINI, L. (2012): 'IP and open innovation: theory and practice'; International Journal of Technology Marketing, vol. 7, n. 2: 119-134. http://dx.doi.org/10.1504/IJTMKT.2012.046903

MIRKOVSKI, K.; LOWRY, P.; B. VON BRIEL, F.; LIU, L. I. (2015): 'The Role of Innovation Intermediaries in Collaborative Networks of Small and MediumSized Enterprises', 19th Pacific Asia Conference on Information Systems (PACIS 2015), Singapore, July 5-9.

OLLILA, S.; ELMQUIST, M. (2011): 'Managing Open Innovation: Exploring Challenges at the Interfaces of an Open Innovation Arena', Creativity and Innovation Management, vol. 20, n. 4: 273-283. http://dx.doi.org/10.1111/j.14678691.2011.00616.x

PROVAN, K.G.; HUMAN, S.E. (1999): “Organizational Learning and the Role of Network Broker in Small-firms Manufacturing Networks", In Grandori A., Interfirm Networks Organization and Industrial Competitiveness, London: Routledge. http://dx.doi.org/10.4324/9780203022481.ch7 
ROIJAKKERS N., ZYNGA A.; BISHOP C. (2014): "Getting help from innomediaries: what can innovators do to increase value in external knowledge searches", In Chesbrough H., Vanhaverbeke W. and West J. (eds.), New frontiers in Open Innovation (pp. 242-255), Oxford (UK): Oxford University Press. http://dx.doi.org/10.1093/acprof:oso/9780199682461.003.0013

SAWHNEY, M.; VERONA, G.; PRANDELLI, E. (2005): 'Collaborating to create: The Internet as a platform for customer engagement in product innovation', Journal of Interactive Marketing, vol. 19, n. 4: 4-17. http://dx.doi.org/10.1002/dir.20046

SIEG, J.H.; WALLIN M.W.; VON KROUGH, G. (2010): 'Managerial challenges in open innovations: a study of innovation intermediation in the chemical industry', $R \& D$ Management, vol. 40, n. 3: 281-291. http://dx.doi.org/10.1111/j. 1467-9310.2010.00596.x

STEWART, J.; HYYSALO, S. (2008): 'Intermediaries, Users and Social Learning in Technological Innovation', International Journal of Innovation Management, vol. 12, n. 3: 295-325. http://dx.doi.org/10.1142/S13639196080020 35

TRAN, Y.; HSUAN, J.; MAHNKE V. (2011): 'How do innovation intermediaries add value? Insight from new product development in fashion markets', $R \& D$ Management, vol. 41, n. 1: 80-91. http://dx.doi.org/10.1111/j.14679310.2010.00628.x

VERONA, G., PRANDELLI, E.; BARBI, E. (2005): 'I Broker tecnologici: un'analisi esplorativa', Economia e politica industriale, vol. 3: 81-106.

WEST, J.; BOGERS, M. (2014): 'Leveraging External Sources of Innovation: A Review of Research on Open Innovation', Journal of Product Innovation Management, vol. 31: 814-831. http://dx.doi.org/10.1111/jpim.12125

WINCH, G.M.; COURTNEY, R. (2007) 'The organization of innovation brokers: An international review', Technology Analysis \& Strategic Management, vol. 19: 747-763. http://dx.doi.org/10.1080/09537320701711223 
YE, J.; KANKANHALLI, A. (2013): 'Exploring innovation through open networks: A review and initial research questions', IIMB Management Review: 114. http://dx.doi.org/10.1016/j.iimb.2013.02.002

YIN, R. K. (1984): Case study research: Design and methods. Sage: Newbury Park (CA).

YIN, R. K. (2003): Case study research: Design and methods (3rd ed.). Sage: Thousand Oaks (CA).

\section{Internet web sites:}

http://www.bigideagroup.net

http://www.ideasproject.com

http://www.innocentive.com

http://www.inpama.com

http://www.mercatodellinnovazione.it

http://www.ninesigma.com

http://www.openideo.com

http://www.openinnovators.net

http://www.pgconnectdevelop.com

http://www.yet2.com 
Annex 1. Services provided by OIIs

\begin{tabular}{|c|c|c|c|c|c|c|c|c|c|c|c|}
\hline \multirow[b]{2}{*}{$\begin{array}{l}\text { Classification } \\
\text { services }\end{array}$} & \multirow[b]{2}{*}{ Services } & \multirow[b]{2}{*}{$\begin{array}{l}\text { Nine- } \\
\text { Sigma }\end{array}$} & \multicolumn{3}{|c|}{ Innocentive } & \multirow[b]{2}{*}{ yet2.com } & \multirow[b]{2}{*}{$\begin{array}{l}\text { Big Idea } \\
\text { Group }\end{array}$} & \multirow[b]{2}{*}{$\begin{array}{l}\text { Big Idea } \\
\text { Group } \\
\text { (Nokia) }\end{array}$} & \multirow[b]{2}{*}{ Openideo } & \multirow[b]{2}{*}{ Inpama } & \multirow[b]{2}{*}{ mercatodellinnovazione. $i$} \\
\hline & & & $\begin{array}{c}\text { Brainstorming } \\
\text { Challenges }^{I}\end{array}$ & $\underset{\text { Challenges }^{2}}{\text { Premium }}$ & $\begin{array}{c}\text { Grand } \\
\text { Challenges }^{3}\end{array}$ & & & & & & \\
\hline \multirow{3}{*}{$\begin{array}{l}\text { Method of } \\
\text { contact } \\
\text { management } \\
\text { between seekers } \\
\text { and solvers }\end{array}$} & $\begin{array}{l}\text { Connection } \\
\text { between solvers } \\
\text { and seekers } \\
\text { managed } \\
\text { through the } \\
\text { platform }\end{array}$ & $\begin{array}{l}\text { YES } \\
(1,2)\end{array}$ & & $\begin{array}{c}\text { YES } \\
\text { Supported } \\
\text { by experts } \\
(1,3)\end{array}$ & $\begin{array}{c}\text { YES } \\
\text { Shaped ad } \\
\text { hoc } \\
(1,3)\end{array}$ & \begin{tabular}{|c|} 
YES \\
Yet2 \\
Strategic \\
Dealflow \\
Service \\
$(1,2,3)$
\end{tabular} & YES & YES & YES & $\begin{array}{c}\text { YES } \\
\text { Only for the } \\
\text { commercialization } \\
\text { of patents } \\
\text { (1) }\end{array}$ & YES \\
\hline & $\begin{array}{l}\text { Connection } \\
\text { between seeker } \\
\text { and solver } \\
\text { communities } \\
\text { managed } \\
\text { autonomously } \\
\end{array}$ & & $\begin{array}{l}\text { YES } \\
(3)\end{array}$ & $\begin{array}{l}\text { YES } \\
\text { (3) }\end{array}$ & $\begin{array}{l}\text { YES } \\
(3)\end{array}$ & YES & & & YES & $\begin{array}{c}\text { YES } \\
\text { Only for the } \\
\text { commercialization } \\
\text { of patents }\end{array}$ & YES \\
\hline & $\begin{array}{l}\text { Purchase and } \\
\text { sale of patents } \\
\text { in the } \\
\text { marketplace }\end{array}$ & & & & & $\begin{array}{c}\text { YES } \\
(1,4,5,6)\end{array}$ & & & & YES & YES \\
\hline $\begin{array}{c}\text { Communication } \\
\text { services }\end{array}$ & $\begin{array}{l}\text { Communication } \\
\text { services }\end{array}$ & $\begin{array}{c}\text { Platform, } \\
\text { e-mail, } \\
\text { personal }\end{array}$ & $\begin{array}{l}\text { Platform, e- } \\
\text { mail }\end{array}$ & $\begin{array}{l}\text { Platform, e- } \\
\text { mail, } \\
\text { telephone }\end{array}$ & $\begin{array}{l}\text { Platform, e- } \\
\text { mail, } \\
\text { personal }\end{array}$ & $\begin{array}{l}\text { Platform, } \\
\text { personal }\end{array}$ & $\begin{array}{l}\text { Platform, } \\
\text { personal }\end{array}$ & \begin{tabular}{|c|} 
Platform, \\
e-mail, \\
personal
\end{tabular} & $\begin{array}{c}\text { Platform, } \\
\text { e-mail }\end{array}$ & Platform, e-mail & Platform, e-mail, personal \\
\hline
\end{tabular}

1. Bakici et al., 2012; ${ }^{2}$. Hakanson et al., 2011; ${ }^{3 .}$ Verona et al., 2005; ${ }^{4 .}$ Huston and Sabbak, 2006; ${ }^{5 .}$ Lichtenthaler and Ernst, 2008; ${ }^{6 .}$ Lopez et al., 2009; ${ }^{7}$ Sieg et al., 2010; ${ }^{8 .}$ Lakhani, 2008; ${ }^{9 \cdot}$ Sahwney et al., 2005.

Source: our work on data from the sites and from the existing literature.

1 "do-it-yourself challenges" through open and collaborative Web 2.0 instruments

${ }^{2}$ Challenges for product innovation (ideas, design, prototypes), connected to Big Data, or for molecule development in pharmaceutical, chemical, and other fields, with specific research partners.

${ }^{3}$ Challenges concerning the big themes in disparate fields (e.g., environment, renewable energy, etc.) 
Annex 1, continued. Services provided by OII

\begin{tabular}{|c|c|c|c|c|c|c|c|c|c|c|c|}
\hline \multirow[b]{2}{*}{$\begin{array}{c}\text { Classificatio } \\
\text { n services }\end{array}$} & \multirow[b]{2}{*}{ Services } & \multirow[b]{2}{*}{ NineSigma } & \multicolumn{3}{|c|}{ Innocentive } & \multirow[b]{2}{*}{$\begin{array}{c}\text { yet2.co } \\
\text { m }\end{array}$} & \multirow{2}{*}{$\begin{array}{c}\text { Big } \\
\text { Idea } \\
\text { Grou } \\
\text { p }\end{array}$} & \multirow{2}{*}{$\begin{array}{c}\text { Big } \\
\text { Idea } \\
\text { Group } \\
\text { (Nokia } \\
\text { ) } \\
\end{array}$} & \multirow[b]{2}{*}{$\begin{array}{c}\text { Openide } \\
\quad \text { o }\end{array}$} & \multirow[b]{2}{*}{$\begin{array}{l}\text { Inpam } \\
\quad \mathbf{a}\end{array}$} & \multirow[b]{2}{*}{$\begin{array}{c}\text { mercatodellinnovazione. } \\
\text { it }\end{array}$} \\
\hline & & & $\begin{array}{l}\text { Brainstormin } \\
\text { g Challenges }\end{array}$ & $\begin{array}{c}\text { Premium } \\
\text { Challenge } \\
\text { s }\end{array}$ & $\begin{array}{c}\text { Grand } \\
\text { Challenges }\end{array}$ & & & & & & \\
\hline \multirow{6}{*}{$\begin{array}{c}\text { Services } \\
\text { providing } \\
\text { support for } \\
\text { contact and } \\
\text { initiation of } \\
\text { innovation } \\
\text { process }\end{array}$} & $\begin{array}{l}\text { Acceptance services, } \\
\text { text preparation, and } \\
\text { revision of post }\end{array}$ & $\begin{array}{c}\text { YES } \\
\text { NineSigma } \\
\text { RFP } \\
(4,6)\end{array}$ & $\begin{array}{l}\text { YES } \\
\text { By the seeker } \\
\text { or through the } \\
\text { community }\end{array}$ & $\begin{array}{l}\text { YES } \\
(7)\end{array}$ & YES & $\begin{array}{c}\text { YES } \\
\text { TechPak } \\
\text { s } \\
(3,4)\end{array}$ & YES & & $\begin{array}{l}\text { YES } \\
\text { Together } \\
\text { with } \\
\text { challenge } \\
\text { sponsor }\end{array}$ & & YES \\
\hline & $\begin{array}{l}\text { Preventive analysis } \\
\text { ideas/demand/proble } \\
\mathrm{m}\end{array}$ & $\begin{array}{c}\text { YES } \\
\text { NineSigma } \\
\text { QuickScan }^{\text {TM }} \\
\end{array}$ & & YES & YES & YES & YES & & YES & & YES \\
\hline & $\begin{array}{l}\text { Evaluation of existing } \\
\text { and emerging } \\
\text { technology to guide } \\
\text { firms in innovation } \\
\text { choices } \\
\end{array}$ & $\begin{array}{c}\text { YES } \\
\text { NineSigma's } \\
\text { Technology } \\
\text { Landscaping }^{T} \\
{ }_{M} \\
\end{array}$ & & & & $\begin{array}{l}\text { YES } \\
(1)\end{array}$ & & & & & YES \\
\hline & $\begin{array}{l}\text { Information } \\
\text { guide/support to a } \\
\text { shared innovation } \\
\text { process }\end{array}$ & $\begin{array}{c}\text { YES } \\
\text { NineSigma } \\
\text { Linked }^{\text {inke }} \\
\text { Innovation }^{T M} \\
\end{array}$ & & YES & YES & YES & YES & & & YES & YES \\
\hline & $\begin{array}{l}\text { Services defining the } \\
\text { price range }\end{array}$ & & YES & YES & YES & & & & & & \\
\hline & $\begin{array}{l}\text { Communication and } \\
\text { distribution services } \\
\text { to community } \\
\text { members or specific } \\
\text { partners }\end{array}$ & $\begin{array}{c}\text { YES } \\
\text { NineSigma } \\
\text { RFP }^{T M}\end{array}$ & $\begin{array}{c}\text { YES } \\
\text { weekly } \\
\text { Newsletter }\end{array}$ & $\begin{array}{c}\text { YES } \\
\text { weekly } \\
\text { Newsletter } \\
\text {, used by } \\
\text { social } \\
\text { media }\end{array}$ & $\begin{array}{l}\text { YES } \\
\text { Completely } \\
\text { personalize } \\
\text { d programs }\end{array}$ & $\begin{array}{l}\text { YES } \\
\text { Tech of } \\
\text { the Week } \\
\text { (3) }\end{array}$ & YES & & $\begin{array}{l}\text { YES } \\
(1)\end{array}$ & YES & \\
\hline
\end{tabular}

1. Bakici et al., 2012; ${ }^{2 .}$ Hakanson et al., 2011; ${ }^{3 .}$ Verona et al., 2005; ${ }^{4 .}$ Huston and Sabbak, 2006; ${ }^{5}$ Lichtenthaler and Ernst, 2008; ${ }^{6 .}$ Lopez et al., 2009; ${ }^{7 .}$ Sieg et al., 2010; ${ }^{8 .}$ Lakhani, 2008; ${ }^{9}$ Sahwney et al., 2005.

Source: our work on data taken from the sites and from the existing literature. 
Annex 1, continued. Services provided by OII

\begin{tabular}{|c|c|c|c|c|c|c|c|c|c|c|c|}
\hline \multirow[b]{2}{*}{$\begin{array}{l}\text { Classification } \\
\text { services }\end{array}$} & \multirow[b]{2}{*}{ Services } & \multirow[b]{2}{*}{ NineSigma } & \multicolumn{3}{|c|}{ Innocentive } & \multirow[b]{2}{*}{ yet2.com } & \multirow{2}{*}{$\begin{array}{c}\text { Big } \\
\text { Idea } \\
\text { Group }\end{array}$} & \multirow{2}{*}{\begin{tabular}{|c|} 
Big \\
Idea \\
Group \\
(Nokia)
\end{tabular}} & \multirow[b]{2}{*}{ Openideo } & \multirow[b]{2}{*}{ Inpama } & \multirow[b]{2}{*}{ mercatodellinnovazione.it } \\
\hline & & & $\begin{array}{c}\text { Brainstorming } \\
\text { Challenges }\end{array}$ & $\begin{array}{l}\text { Premium } \\
\text { Challenges }\end{array}$ & $\begin{array}{c}\text { Grand } \\
\text { Challenges }\end{array}$ & & & & & & \\
\hline \multirow{5}{*}{$\begin{array}{l}\text { Services } \\
\text { providing } \\
\text { support for } \\
\text { contact and } \\
\text { initiation of } \\
\text { innovation } \\
\text { process } \\
\text { (sequel) }\end{array}$} & $\begin{array}{l}\text { Support } \\
\text { services by } \\
\text { experts on } \\
\text { request/project }\end{array}$ & $\begin{array}{l}\text { YES } \\
\text { Expert } \\
\text { advisory } \\
\text { service } \\
(1)\end{array}$ & & $\begin{array}{c}\text { YES } \\
\text { With a } \\
\text { standard } \\
\text { process } \\
(3,7,8)\end{array}$ & $\begin{array}{c}\text { YES } \\
\text { With ad } \\
\text { hoc } \\
\text { process (8) }\end{array}$ & YES & & & $\begin{array}{l}\text { YES } \\
(1)\end{array}$ & $\begin{array}{c}\text { YES } \\
\text { Contacted } \\
\text { directly } \\
\text { by the } \\
\text { seeker }\end{array}$ & YES \\
\hline & $\begin{array}{l}\text { Services } \\
\text { seeking } \\
\text { specialized } \\
\text { partners in } \\
\text { answer to } \\
\text { prerequisites } \\
\text { dictated by the } \\
\text { firm }\end{array}$ & $\begin{array}{c}\text { YES } \\
\text { NineSigma } \\
\text { Targeted } \\
\text { Partner } \\
\text { Search }^{T M}\end{array}$ & & $\begin{array}{l}\text { YES } \\
(1)\end{array}$ & YES & YES & & & & YES & \\
\hline & $\begin{array}{l}\text { Creation of ad } \\
\text { hoc group } \\
\text { services for the } \\
\text { resolution of } \\
\text { problems }\end{array}$ & $\begin{array}{c}\text { YES } \\
\text { NineSigma } \\
\text { Linked } \\
\text { Innovation }^{T M} \\
(1,9) \\
\end{array}$ & & YES & YES & $\begin{array}{l}\text { YES } \\
(9)\end{array}$ & $\begin{array}{l}\text { YES } \\
(1)\end{array}$ & & & YES & YES \\
\hline & $\begin{array}{l}\text { Monitoring } \\
\text { throughout the } \\
\text { entire } \\
\text { innovation } \\
\text { process }\end{array}$ & $\begin{array}{c}\text { YES } \\
\text { NineSigma } \\
\operatorname{RFP}^{T M}\end{array}$ & & YES & YES & YES & YES & & $\begin{array}{l}\text { YES } \\
(1)\end{array}$ & & $\begin{array}{c}\text { YES } \\
\text { By at least two experts }\end{array}$ \\
\hline & $\begin{array}{l}\text { Definition and } \\
\text { evaluation of } \\
\text { solutions found }\end{array}$ & & & YES & YES & $\begin{array}{l}\text { YES } \\
(1)\end{array}$ & YES & & YES & & \\
\hline
\end{tabular}

1. Bakici et al., 2012; 2. Hakanson et al., 2011; 3. Verona et al., 2005; 4. Huston and Sabbak, 2006; 5.

Lichtenthaler and Ernst, 2008; 6. Lopez et al., 2009; 7. Sieg et al., 2010; 8. Lakhani, 2008; 9. Sahwney et al., 2005.

2. Source: our work on data taken from the sites and from the existing literature. 
Annex 1, continued. Services provided by OII

\begin{tabular}{|c|c|c|c|c|c|c|c|c|c|c|c|}
\hline \multirow[b]{2}{*}{$\begin{array}{l}\text { Classificatio } \\
\text { n services }\end{array}$} & \multirow[b]{2}{*}{ Services } & \multirow[b]{2}{*}{ Nine-Sigma } & \multicolumn{3}{|c|}{ Innocentive } & \multirow[b]{2}{*}{ yet2.com } & \multirow[b]{2}{*}{ Big Idea Group } & \multirow{2}{*}{$\begin{array}{l}\text { Big Idea } \\
\text { Group } \\
\text { (Nokia) }\end{array}$} & \multirow[b]{2}{*}{ Openideo } & \multirow[b]{2}{*}{ Inpama } & \multirow{2}{*}{$\begin{array}{c}\text { mercatodell } \\
\text { innovazione } \\
\text {.it }\end{array}$} \\
\hline & & & $\begin{array}{l}\text { Brainstorming } \\
\text { Challenges }\end{array}$ & $\begin{array}{l}\text { Premium } \\
\text { Challenges }\end{array}$ & $\begin{array}{c}\text { Grand } \\
\text { Challenges }\end{array}$ & & & & & & \\
\hline \multirow{2}{*}{$\begin{array}{l}\text { Technical- } \\
\text { technologica } \\
\text { I support for } \\
\text { innovation }\end{array}$} & $\begin{array}{l}\text { Product design support through } \\
\text { prototype }\end{array}$ & $\begin{array}{c}\text { YES } \\
\text { NS } S^{2} \text { Accelerated In- } \\
\text { Market Solutions } \\
\text { together with } \\
\text { Nottingham Spirk }\end{array}$ & & YES & & & YES & & $\begin{array}{l}\text { YES Process } \\
\text { shared with } \\
\text { the } \\
\text { community }\end{array}$ & & \\
\hline & $\begin{array}{l}\text { Innovation launch support and } \\
\text { licence-out services }\end{array}$ & $\begin{array}{c}\text { YES } \\
\text { Open Innovation } \\
\text { Roadmap } \\
(5,6) \\
\end{array}$ & $\begin{array}{l}\text { YES } \\
(6,8)\end{array}$ & $\begin{array}{l}\text { YES } \\
(1,6,8)\end{array}$ & $\begin{array}{l}\text { YES } \\
(1,6,8)\end{array}$ & $\begin{array}{l}\text { YES } \\
(1,3,6)\end{array}$ & YES & & & YES & \\
\hline \multirow{2}{*}{$\begin{array}{c}\text { Technical- } \\
\text { technologica } \\
\text { I } \\
\text { consultancy } \\
\text { services to } \\
\text { the firm }\end{array}$} & $\begin{array}{l}\text { Existing technology } \\
\text { improvement services and/or } \\
\text { integrable to firm (e.g., } \\
\text { adherance to norms or vertical } \\
\text { integration) } \\
\end{array}$ & $\begin{array}{c}\text { YES } \\
\text { Technology } \\
\text { Search }^{T M}\end{array}$ & & & & $\begin{array}{l}\text { YES } \\
(3)\end{array}$ & & & & & YES \\
\hline & $\begin{array}{l}\text { Support in the identification of } \\
\text { aspects and/or projects for } \\
\text { major investment }\end{array}$ & $\begin{array}{c}\text { YES } \\
\text { NineSigma's } \\
\text { Technology } \\
\text { Landscaping } \\
\end{array}$ & & & & & & & & & YES \\
\hline \multirow{5}{*}{$\begin{array}{l}\text { Other } \\
\text { consultancy } \\
\text { services }\end{array}$} & $\begin{array}{l}\text { Organizational and financial } \\
\text { consultancy services }\end{array}$ & & & & & & YES & & & YES & \\
\hline & $\begin{array}{l}\text { Consultancy on suppliers and } \\
\text { supply chain management }\end{array}$ & & & & & & YES & & & YES & \\
\hline & $\begin{array}{l}\text { Partner seeking services for } \\
\text { venture capital operations }\end{array}$ & & & & & YES & YES & & & YES & \\
\hline & $\begin{array}{l}\text { Marketing services (e.g., } \\
\text { communications) }\end{array}$ & & & & & & YES & & & YES & \\
\hline & Internationalization support & & & & & & & & & & YES \\
\hline
\end{tabular}


Annex 1. Services provided by OII (sequel)

\begin{tabular}{|c|c|c|c|c|c|c|c|c|c|c|c|}
\hline \multirow[b]{2}{*}{$\begin{array}{c}\text { Classification } \\
\text { services }\end{array}$} & \multirow[b]{2}{*}{ Services } & \multirow[b]{2}{*}{ Nine-Sigma } & \multicolumn{3}{|c|}{ Innocentive } & \multirow[b]{2}{*}{ yet2.com } & \multirow{2}{*}{$\begin{array}{c}\text { Big } \\
\text { Idea } \\
\text { Group }\end{array}$} & \multirow{2}{*}{\begin{tabular}{c|} 
Big \\
Idea \\
Group \\
(Nokia)
\end{tabular}} & \multirow[b]{2}{*}{ Openideo } & \multirow[b]{2}{*}{ Inpama } & \multirow[b]{2}{*}{ mercatodellinnovazione.it } \\
\hline & & & $\begin{array}{c}\text { Brainstorming } \\
\text { Challenges }\end{array}$ & $\begin{array}{c}\text { Premium } \\
\text { Challenges }\end{array}$ & $\begin{array}{c}\text { Grand } \\
\text { Challenges }\end{array}$ & & & & & & \\
\hline \multirow{3}{*}{$\begin{array}{c}\text { Other } \\
\text { services } \\
\text { and/or } \\
\text { innovation } \\
\text { opportunities }\end{array}$} & $\begin{array}{l}\text { Training and } \\
\text { coaching } \\
\text { services }\end{array}$ & YES & & & & & & & & & \\
\hline & $\begin{array}{l}\text { Psychometric } \\
\text { tests for team } \\
\text { leaders and } \\
\text { project } \\
\text { managers }\end{array}$ & $\begin{array}{c}\text { YES } \\
\text { The } \\
\text { Collaborative } \\
\text { Innovation } \\
\text { Profile } \\
\text { together with } \\
\text { Caliper } \\
\end{array}$ & & & & & & & & & \\
\hline & $\begin{array}{l}\text { Possibility of } \\
\text { participating in } \\
\text { big innovation } \\
\text { projects in } \\
\text { fields of great } \\
\text { interest } \\
\text { worldwide (e.g., } \\
\text { in environment } \\
\text { ) }\end{array}$ & $\begin{array}{c}\text { YES } \\
\text { NineSigma, } \\
\text { Grand } \\
\text { Challenge }^{\mathrm{TM}}\end{array}$ & & & $\begin{array}{c}\text { YES } \\
\text { Stimulated } \\
\text { by seekers }\end{array}$ & & & & $\begin{array}{c}\text { YES } \\
\text { Big } \\
\text { challenges } \\
\text { for social } \\
\text { good }\end{array}$ & & \\
\hline
\end{tabular}

Source: our work on data taken from the sites and from the existing literature. 
Annex 2: OII services linked to general roles and functions

\begin{tabular}{|c|c|c|}
\hline Roles & Functions & Services provided by OIIs \\
\hline $\begin{array}{l}\text { Networking } \\
\begin{array}{l}\text { (Gassmann } \text { et al., 2011; Agogue et } \\
\text { al., 2013) }\end{array}\end{array}$ & $\begin{array}{l}\text { To connect, involve and mobilize large number of actors (Hakanson } \\
\text { et al., 2011; Agogue et al., 2013). }\end{array}$ & $\begin{array}{l}\text { - Connection services between seekers and solvers direct (Innocentive, Yet2.com, Openideo, Inpama for } \\
\text { patents,Mercatodel, linnovatione.it) and through the platform (all eight platforms); } \\
\text { - Support services by experts on request/project (Nine-Sigma, Innocentive except for Brainstorming } \\
\text { Challenges, Yet2.com, Openideo, Inpama, Mercatodellinnovazione.it); } \\
\text { - Services seeking specialized partners in answer to prerequisites suggested by the firm (NineSigma, } \\
\text { Innocentive except for Brainstorming Challenges, Yet2.com, Inpama); } \\
\text { - Creation of ad hoc group services for the resolution/response to problems (NineSigma, Innocentive } \\
\text { except for Brainstorming Challenges, Yet2.com, Big Idea Group, Inpama, Mercatodellinnovazione.it); } \\
\text { - Purchase and sale of patents for OII which are marketplaces (Yet2.com, Inpama, } \\
\text { Mercatodellinnovazione.it). }\end{array}$ \\
\hline $\begin{array}{l}2 . \quad \text { Intermediation for } \\
\text { technology transfer } \\
\text { (Lichtenthaler and Ernst, 2008; } \\
\text { Agogue et al., 2013) }\end{array}$ & $\begin{array}{l}\text { To facilitate the identification of technology commercialization } \\
\text { opportunities (Lichtenthaler and Ernst, 2008) and the diffusion of } \\
\text { technology transfer (Diener and Piller, 2010). } \\
\text { "Accreditation, validation and regulation, protection of the results, } \\
\text { commercialisation and evaluation of outcomes" (Howells, 2006, p. } \\
\text { 721). }\end{array}$ & $\begin{array}{l}\text { - Definition and evaluation of solutions found (Innocentive except for Brainstorming Challenges, Yet2.com, } \\
\text { Big Idea Group, Openideo); } \\
\text { - Services defining the prize range (Innocentive); } \\
\text { - Searching for commercialization opportunities through networking (all platforms, for details look to the } \\
\text { previous raw). }\end{array}$ \\
\hline $\begin{array}{l}\text { 3. Knowledge } \\
\text { transfer/experience sharing } \\
\text { (Diener and Piller, 2010; Gassmann } e t \\
\text { al., 2011) }\end{array}$ & $\begin{array}{l}\text { Knowledge processing and combination/recombination by } \\
\text { connecting companies with problems to a broad range of solvers } \\
\text { from different domains and industries (Howells, 2006; Stewart and } \\
\text { Hyysalo, 2008; Lopez and Vanhaverbeke, 2009; Sieg et al., 2010; } \\
\text { Hakanson et al., 2011; Bakici et al., 2012; Ye and Kankanhalli, } \\
\text { 2013). }\end{array}$ & $\begin{array}{l}\text { - Information guide/support to a shared innovation process (NineSigma, Innocentive except for } \\
\text { Brainstorming Challenges, Yet2.com, Big Idea Group, Inpama, Mercatodellinnovazione.it); } \\
\text { - Monitoring throughout the entire innovation process (all platforms except Innocentive for Brainstorming } \\
\text { Challenges, Big Idea Group, Impama); } \\
\text { - Communication and distribution services towards community members and/or specific partners (all } \\
\text { platforms except Big Idea Group, Mercato dellinnovazione.it). }\end{array}$ \\
\hline $\begin{array}{l}4 . \quad \text { Problem Solving } \\
\text { (Agogue et al., 2013) }\end{array}$ & $\begin{array}{l}\text { To solve (or mitigate) conflicts among stakeholders (Agogue } e t \text { al., } \\
\text { 2013). }\end{array}$ & $\begin{array}{l}\text { - Techno-technological support services for innovation: (a) Product design support through to prototype } \\
\text { (NineSigma, Innocentive for Premium Challenges, Big Idea Group, Openideo); (b) Innovation launch } \\
\text { support and licence-out services (NineSigma, Innocentive, Yet2.com, Big Idea Group, Inpama); } \\
\text { - Other consultancy services: organizational and financial, on suppliers and supply chain management, } \\
\text { partner seeking services for venture capital operations, marketing services for Big Idea Group, Inpama; } \\
\text { partner seeking services for venture capital operations for Yet2.com; internationalization support for } \\
\text { Mercatodellinnovazione.it; training and coaching services and psychometric tests for team leaders and } \\
\text { project managers only for NineSigma). }\end{array}$ \\
\hline \multirow[t]{2}{*}{$\begin{array}{l}\text { 5. Scanning information } \\
\text { and articulating needs } \\
\text { (Diener and Piller, 2010; Gassmann } e t \\
\text { al. 2011) }\end{array}$} & $\begin{array}{l}\text { Foresight and diagnostics, scanning and information processing } \\
\text { (Howells, 2006). } \\
\text { Working closely with clients (seekers) to define the problems and to } \\
\text { find possible solvers (Ye and Kankanhalli, 2013). } \\
\text { Brokering information flows, filling information gaps (Diener and } \\
\text { Piller, 2010). }\end{array}$ & $\begin{array}{l}\text { - Acceptance services, text preparation and revision of post (all platforms except Big Idea Group, Inpama); } \\
\text { - Preventive analysis ideas/demand/problem (all platforms except Innocentive-Brainstorming challenges, } \\
\text { Big Idea Group and Inpama); } \\
\text { - Evaluation of existing and emerging technology to guide the firm in the innovation choice (NineSigma, } \\
\text { Yet2.com, Mercatodellinnovazione.it); } \\
\text { - Technic-technological consultancy services to the seeker (NineSigma, Yet2.com only for Existing } \\
\text { technology improvement services and/or integrable to firm, Mercatodellinnovazione.it). }\end{array}$ \\
\hline & OII own functioning activities & $\begin{array}{l}\text { - Communication services (online for all platforms, personal only for NineSigma, Innocentive-Grand } \\
\text { Challenges, Yet2.com, Big Idea Group, Big Idea Group, Mercato dellinnovazione.it) } \\
\text { - Other innovation opportunities provided by the OII (NineSigma, Innocentive - Grand Challenges, } \\
\text { Openideo). }\end{array}$ \\
\hline
\end{tabular}

